\title{
Journal of General Medicine and Clinical Practice
}

Jesús Cuéllar Álvarez ${ }^{1}$, J General Medicine and Clinical Practice http://dx.doi.org/10.31579/jgmcp.2018/1.10064.

Characterization of the Functional State in Fragile Bigger Adults from the Medical Practice Jesús Cuéllar Álvarez ${ }^{1}$, Aguedo Medardo Treto ${ }^{2}$,Vivian Margarita Guerra Morales ${ }^{3}$

${ }^{1}$ Central University "Marta Abreu" of Las Villas. Cuba. Department of Psychology

${ }^{2}$ Medical Institution: "Celestino Hernández". Assistant teacher. Second degree specialist in surgery.

${ }^{3}$ Central University "Marta Abreu" of Las Villas. Cuba. Titular teacher. Department of Psychology.

*Corresponding Author : Jesús Cuéllar Álvarez, Department of Clinical Psychologist. Tel +53 54785830, Email: jesusca@infomed.sld.cu Received date: August 28,2018; Accepted date : September 14,2018; Published date: September 24,2018.

Citation for this Article: Jesús Cuéllar Álvarez, Aguedo Medardo Treto, Vivian Margarita Guerra Morales. Characterization of the Functional State in Fragile Bigger Adults from the Medical Practice, J. General Medicine and Clinical Practice, Doi: http://dx.doi.org/ 10.31579/ jgmcp.2018/1.10064.

Copyright : (C) 2018. Jesús Cuéllar Álvarez et al. This is an open-access article distributed under the terms of the Creative Commons Attribution License, which permits unrestricted use, distribution, and reproduction in any medium, provided the original author and source are credited.

\section{Abstract \\ Context}

The fragility of the elderly served in a community health area and to characterize elderlies according to fragility criteria.

\section{Objective}

To characterize the functional state in fragile bigger adults from the medical practice.

\section{Material and Methods}

A descriptive, cross-sectional investigation with a quantitative approach was carried out between April 2017 and April 2018.

\section{Results}

Prevailed the alterations of mobility and balance in $54,8 \%$, only $16,1 \%$ was alterations of the emotional state and 29,0 $\%$ was alterations functional cognitive.

\section{Conclusion}

The presence of several fragility criteria such as elderlies older female sex with associated pathologies as hypertension.

Keywords

frail elderly; functional state; aging; fragility; risk factors.

\section{Introduction}

The fragility is described as a biological syndrome in which takes place decrease of the physiologic reservation and an increase from the resistance to the factors of risks as a result of the progressive deterioration of the physiologic systems. ${ }^{1}$

It can stand out that the fragile bigger adults demand more and more and better attentions of health, although the resources are not adapted and it is complex when introducing to the social system a numerous bigger population of adults and in permanent increase. ${ }^{\mathbf{2 , 3}}$

Cuba is already a country example with its population's important aging: The $15,3 \%$ of the Cubans is 60 years old or more, it calculates that it will increase, according to estimates, to almost $25 \%$ in the 2025 and to more than $30 \%$ in the $2050 .{ }^{4}$

The aging is a progressive, intrinsic and universal process that happens in all alive being as a consequence of the interaction of the individual's genetics and its environment with the time. It can also be defined as all the alterations that take place in an organism with the step of the time and that they drive to functional losses and the death. ${ }^{\mathbf{5}}$

Its increment in the last years imposes an inevitable challenge to the sanitary strategies for the sake of to satisfy its necessities and to offer them the possibility to live with more quality of life. ${ }^{6}$

The fragile term means, according to the dictionary, something weak that can break with easiness. For the doctors it is easy to imagine the meaning and to manage patient fragile every day, although from the theoretical point of view it can be difficult their description, in such a way that doesn't still have a clear definition of the fragility that satisfies to clinical and investigators. ${ }^{7}$

Auctores Publishing - Volume1-10064 www.auctoresonline.org Page - 01
At the moment it represents a problem of health in institutions of the primary level of attention in Cuba and especially in the municipality of Santa Clara, belonging to the county of Villa Clara like one of the most aged region in the whole country and where the old man deserves all the integral attention of health starting from his state of fragility from the daily medical practice.

The objective of the present investigation was to characterize the functional state in fragile bigger adults from the medical practice.

\section{Material and Methods}

A descriptive, cross-sectional study with a quantitative approach was carried out in elderly patients attended from a community health area, from April 2017 to April 2018. The sample was selected through the simple random sampling probabilistic technique and consisted of 31 patients.

\section{Empiric level}

Clinical history of health: it was applied with the objective of determining the variables of sex socio demographic belonging to the study.

Open interview: it was applied with the objective of knowing the factors of risks that the biggest adults possess and that they limit their appropriate operation.

Geriatric of Functional Evaluation climbs: it was applied with the objective of identifying the approaches of fragility in the biggest adults that hinder their operation level. 


\section{Inclusion approaches}

I. Patients of both sexes, older adults between 60 to 80 years of age with a deficit in their level of functioning.

II. Elderly patients who give their consent to participate in the investigation.

\section{Exclusion approaches}

III. Patients of both sexes, older adults between 60 to 80 years of age with psychiatric antecedents.

IV. Elderly patients who give their consent to participate in the investigation.

\section{Exit approaches}

VI. Patients that abandon the investigation voluntarily.

\section{Collection of the information}

For the collection of information, a form was designed with the variables that were to be investigated, which included general data, such as age, sex, approach of fragility and risk factors in the biggest adult. In addition, the open interview was conducted, with prior informed consent, to determine compliance with the functional indicators of cognitive rehabilitation and which allowed psychological evaluation; the Mini-mental test and the Katz index were used.

\section{Statistical analysis}

Once the information was collected, an automated database was created, supported on Windows Microsoft Excel, from which the frequency distributions for the tables and graphs that summarized the primary data were extracted. Descriptive statistics techniques were applied to obtain absolute frequencies and percentages.

\section{Results}

\begin{tabular}{|c|c|c|c|c|c|c|c|c|}
\hline \multirow[t]{3}{*}{ Sex } & \multicolumn{6}{|c|}{ Age of Group } & \multirow{2}{*}{\multicolumn{2}{|c|}{ Total }} \\
\hline & \multicolumn{2}{|c|}{$60-69$} & \multicolumn{2}{|c|}{$70-75$} & \multicolumn{2}{|c|}{$76-80$} & & \\
\hline & No. & $\%$ & No. & $\%$ & No. & $\%$ & No. & $\%$ \\
\hline $\begin{array}{l}\text { Fema } \\
\text { le }\end{array}$ & 9 & 29,0 & 6 & 19,3 & 2 & 6,4 & 17 & 54,8 \\
\hline Male & 6 & 19,3 & 5 & 16,1 & 3 & 9,7 & 14 & 45,2 \\
\hline Total & 15 & 48,4 & 11 & 35,5 & 5 & 16,1 & 31 & 100,0 \\
\hline
\end{tabular}

Table 1: Distribution of fragile bigger adults according to age and sex.

Source : Clinical history of health

In the studied sample, the female sex predominated $(54,8 \%)$ and the group from 60 to 69 years with $48,4 \%$ (Table 1 ).

\begin{tabular}{|l|l|l|}
\hline Approach of fragility & No. & $\%$ \\
\hline Alterations of mobility and balance & 17 & 54,8 \\
\hline Alterations functional cognitive & 9 & 29,0 \\
\hline Alterations of the emotional state & 5 & 16,1 \\
\hline Total & 31 & 100,0 \\
\hline
\end{tabular}

Table 2 : Distribution of fragile bigger adults according to approach of fragility

\section{Source : Geriatric of Functional Evaluation climbs}

To analyze the functional factors, the approach of fragility was applied where they were alterations of mobility and balance in $54,8 \%$, only $16,1 \%$ was alterations of the emotional state (table 2) and $29,0 \%$ was alterations of the emotional state.

\begin{tabular}{|l|l|l|}
\hline Risk factors & No. & \% \\
\hline Faulty nutrition & 17 & 54,8 \\
\hline Domestic accidents & 9 & 29,0 \\
\hline Hypertension & 5 & 16,1 \\
\hline Total & 31 & 100,0 \\
\hline
\end{tabular}

Table 3 Distribution of fragile bigger adults according to risk factors

Source: Open interview

To analyze the risk factors, the approach of fragility was applied where they were faulty nutrition in $54,8 \%$, only $16,1 \%$ was hypertension (table 3 ) and 29,0\% was domestic accidents.

\section{Discussion}

The aging process intrinsically involves the reduction of physical capacity and the development of cognitive impairment of an individual however, various pathologies and lifestyle.

The carried out investigations, they reflect these characteristics, with relationship to the age, it is also necessary to keep in mind that the fragility increases with the age and on the other hand the expectation of life in the Cubans after the 80 years increases ${ }^{7}$ años what elevates its quality of life with better sanitary attention.

There are authors that outline that the feminine population has a bigger hope of life that the masculine population, ${ }^{8}$ what belongs together with that reflected in the study.

Other authors ${ }^{9}$ outline that the young bigger adults (young old men) category of those that are between 60 and 75 years, suffers at least of 1 illness of the no transmissible chronicles, the old means, between 76 and 84 years suffer at least of 2 of the no transmissible chronicles and the old men, those that surpass the 85 years suffer 3 or more than these entities, that which coincides with the carried out study.

From the practical point of view for the doctors could be easy to define to newspaper a fragile old man if associates to something weak that breaks, however from the theoretical point of view it is difficult in such a way pus doesn't still have a clear definition of the fragility that satisfies to clinical and investigators. ${ }^{\mathbf{1 0}}$

Consequently, old age is the inevitable result of organic and mental deterioration, which becomes visible in the middle of life and progresses at an accelerated rate.

Aging as a biological process has extensive social and psychological consequences; unfortunately in the world today and especially in the province of Villa Clara the demographic indicators have been growing in an ascending way, which implies that older adults demand integrated actions with the help of professionals and intervention from different sectors to cover the different biological, psychological and social needs. ${ }^{\mathbf{1 1}}$

Sad mood should not be part of normal aging and is not a natural and inevitable accompaniment of the decline of social attitude, several works $\mathbf{1 2}$ have shown that depressive symptoms are related to poor health and functional disability, so it is considered as a very important public health problem and its study is an integral part of research on the welfare and health of the elderly.

The interest for the life style adjusted to the cognitive, affective and physical functioning in the elderly, means that through follow-up and assistance with the help of the various professionals involved in the direct work in rehabilitation, they achieve an adequate active or successful aging. Primary process that involves gradual and unavoidable age-related changes that appears in all members of a species. ${ }^{13}, \mathbf{1 4}$

\section{Conclusion}

You conclude with the presence of several approaches of fragility in bigger old men where the feminine sex prevails with pathologies associated of hypertension and inadequate lifestyle.

The mobility is affected by different factors of risks: as they are, faulty nutrition, muscular weakness and domestic accidents. Is also attributed to the morphological and functional alterations that appear in the body and in the sensorial system due to the practice of physical exercises. 


\section{References}

1. Roig Hechavarría C, Vega Bonet V, Ávila Fer-nández E, Ávila Fernández B, Gil Gillins Y. Apli-cación de terapia cognitivo conductual para elevar la autoestima del adulto mayor en Casas de abuelos. Correo cient méd holguín [Internet]. 2011 [citado 12 Jul 2017]; 15(2):[aprox. 4 p.]. Disponible en

2. Roqué Sánchez MV, Gonzalvo Cirac M. Demo-grafía, población vulnerable y bioética. Persbioét [Internet]. 2015 [citado 21 Jul 2017];19(2):[aprox. 18 p.]. Disponible en: http://www.scielo.org.co/scielo.php?script=sci_arttext\&pid=S0 123-31222015000200005\&lng=pt

3. Urciaga Campos JA. Construcción del Estado en América del Sur: Apuntes sobre una sociode-mografía histórica en el siglo XIX. Rev Nov Pob [Internet]. 2015 [citado 21 Jul 2017];11(21):[aprox. 14 p.]. Disponible en: http://scielo.sld.cu/ scielo.php?script=sci_arttext\&pid=S181740782015000100010\&lng=pt\&tlng=es

4. Cardona Arango D, Peláez E. Envejecimiento poblacional en el siglo XXI: oportunidades, retos y preocupaciones. Salud Uninorte [Internet]. 2012 [citado 15 Feb 2015];28(2). Disponible en: http://www.redalyc.org/pdf/817/81724957014. pdf

5. Jaque Lara R. Envejecimiento de la población. Revista Chilena de Salud Pública. 2011:14(2):291-310.

6. Collazo Ramos MI, Calero Ricardo JL, Rodrí-guez Cabrera AL. Necesidades, realidades y po-sibilidades del sistema de salud cubano para su enfrentamiento al envejecimiento poblacional. Rev Cub Sal Pub [Internet]. 2010 [citado 15 Jul 2017];36(2):[aprox. 7 p.].Disponible en: http://scielo.sld.cu/ scielo.php?pid=S0864-34662010000200009\&script=sci_art text

7. Llanes Betancourt C. Evaluación funcional y anciano frágil. Rev Cubana Enfermer [Internet]. 2008 Jun [citado 16 Abr 2014];24(2). Disponible en: http://scielo.sld.cu/scielo.php? script=sci_arttext\&pid=S0864-03192008000200005\&lng=es.

8. Vega García E, Menéndez Jiménez JE, Rodríguez Rivera L, Ojeda Hernández M, Leyva Salermo B, Cardoso Lunar N, et al. Medicina General Integral. La Habana: Ciencias Médicas; 2008. p. 274-309.T1.
9. Arias López Y, Quiñones Rodríguez MC, Rodríguez Marín O, Tejera Valdés AJ, Delgado Martínez EM. Estrategia educativa para modificar variables psicológicas en el adulto mayor institucionalizado. Mediciego [Internet]. 2013 [citado 16 Abr 2014];19(2). Disponible en: http://bvs.sld.cu/revistas/ mciego /vol19_no2_2013/articulos/t-1.html

10. Jürschik Giménez P. Criterios de fragilidad del adulto mayor. Estudio piloto. Atención Primaria. 2011;43(4):190-196.

11. Marinês Tambara L, Castioni D, Kirchner RM, Hildebrandt LM. Capacidad funcional y nivel cognitivo de adultos mayores residentes en una comunidad en el sur de Brasil. Enferm Glob [Internet]. 2015 [citado $201722 \mathrm{Mar}$ ]; 14(37): aprox. $11 \mathrm{p}$. Disponible en: http://scielo.isciii. es/pdf/eg/v14n37/clinica1 .pdf.

12. Rodríguez Blanco L, Sotolongo Arró O, Luberta Noy G, Calvo Rodríguez M. Comportamiento de la depresión en el adulto mayor del policlínico "Cristóbal Labra". Rev Cub Med Gen Integr [Internet]. 2013 [citado 201722 Mar]; 29(1): 64-75 p. Disponible en: http:// scielo.sld.cu/ pdf/mgi/v29n1/mgi09 113.pdf.

13. Clemente F. Reducción de la ansiedad, la depresión geriátrica y la preocupación en una muestra de adultos mayores a través de un programa de entrenamiento en mindfulness. Ter Psicol [Internet]. 2013 [citado 201722 Mar]; 35(1): 71-79 p. Disponible en: https://scielo .conicyt.cl/pdf/terpsicol/v35n1/ art07.pdf.

14. Segura Cardona A, Cardona Arango D, Segura Cardona A, Garzón Duque M. Riesgo de depresión y factores asociados en adultos mayores. Antioquia, Colombia-2012. Rev Salud Pública [Internet]. 2015 [citado 201722 Mar]; 17(2): 184-194 p. Disponible en: http://www. scielo.org.co/pdf/rsap/v17n2/v17n2a03.pdf. 